\title{
Bronchoalveolar lavage cell populations in bleomycin lung toxicity
}

\author{
DOROTHY A WHITE, MARK G KRIS, DIANE E STOVER \\ From the Department of Medicine, Memorial Sloan Kettering Cancer Center, New York
}

\begin{abstract}
Bleomycin is an antineoplastic drug with a well documented capability of causing pulmonary fibrosis. ${ }^{1}$ Bronchoalveolar lavage studies performed with animal models of bleomycin toxicity have shown accumulation of inflammatory cells in the alveoli before the development of fibrosis. ${ }^{23}$ Polymorphonuclear leucocytes are the first cells to appear and are consistently present after the acute injury. ${ }^{23}$ Eosinophils and lymphocytes in lavage fluid have also been found to be transiently increased early in the development of fibrosis. ${ }^{245}$ In this paper we report lavage cell differentials in four patients with bleomycin pneumonitis. Our findings are similar to those obtained in patients with idiopathic pulmonary fibrosis and are also consistent with the results of studies on animal models of bleomycin toxicity.
\end{abstract}

\section{Methods}

The four patients with bleomycin toxicity were referred to the pulmonary service at Memorial Hospital for evaluation of infiltrates or respiratory symptoms (or both) occurring during bleomycin administration. All were non-smokers. Data on the patients are given in table 1. Pulmonary function was assessed in three patients and showed evidence of interstitial disease with a low diffusing capacity in each case, including patient number 3 , who had a normal chest radiograph. Investigations included bronchoscopy with bronchoalveolar lavage and transbronchial biopsy. Cultures and special stains of bronchoscopy specimens showed no evidence of infection. Biopsy specimens showed hyperplasia of type II pneumocytes, consistent with a drug effect, in all patients and fibrosis was present in three cases. All the patients were treated with corticosteroids only and no other cause of interstitial disease was identified during follow up over several months.

A control group consisted of six patients who underwent bronchoalveolar lavage and whose lungs either were normal or had only a local lesion. Their average age was 50 (SD 4) years and all were non-smokers.

Bronchoalveolar lavage was performed in the usual manner as previously described. ${ }^{6}$ Cells were removed from the lavage fluid by centrifugation ( $500 \mathrm{~g}$ for 10 minutes). The total number of cells present was determined with a hae-

Address for reprint requests: Dr Dorothy A White, Memorial Hospital, 1275 York Avenue, New York, New York 10021, USA.

Accepted 23 June 1986 mocytometer and differential cell counts were performed on cytocentrifuge preparations with Wright's stain.

Statistical analyses were performed with the Wilcoxon two sample rank sum test and Student's $t$ test.

\section{Results}

Bronchoalveolar lavage samples from patients with bleomycin pulmonary toxicity contained $7.7 \times 10^{6}$ cells $/ 100 \mathrm{ml}$ lavage fluid, which was similar to the $6.5 \times 10^{6}$ cells $/ 100 \mathrm{ml}$ in our control subjects. The differential cell count (table 2) showed significantly greater percentages and absolute numbers of polymorphonuclear leucocytes and eosinophils in those with bleomycin toxicity than in controls $(p<0.01)$.

\section{Discussion}

Bronchoalveolar lavage is a valuable technique for sampling lower respiratory cells and secretions in diffuse interstitial lung disease. ${ }^{6}$ Investigations in animal models of bleomycin toxicity have shown serial changes in lavage fluid during development of fibrosis. Thrall $e t a^{2}$ found that after intratracheal injection of bleomycin in the rat there was a significant influx of inflammatory cells. Neutrophils were the first to appear and increased percentages persisted even after the total number of cells recovered returned to normal. Increased percentages of lymphocytes were noted in the lavage fluid for a shorter time early in the development of fibrosis, and transitory influx of eosinophils was also found. ${ }^{2} 5$

Fahey $e \mathrm{al}^{3}$ treated mongrel dogs with twice weekly intravenous bleomycin, which led to histologically documented fibrosis after 14-16 weeks of treatment. A significant increase in the percentage of lavage polymorphonuclear leu-

\section{Table 1 Characteristics of the patients}

\begin{tabular}{|c|c|c|c|c|c|}
\hline $\begin{array}{l}\text { Patient } \\
\text { No }\end{array}$ & $\begin{array}{l}\text { Age } \\
\text { (y) }\end{array}$ & Sex & Tumour & $\begin{array}{l}\text { Bleomycin } \\
\text { dose } \\
\text { (units) }\end{array}$ & Radiograph \\
\hline 1 & 63 & $\mathbf{M}$ & $\begin{array}{l}\text { Pyriform } \\
\text { sinus }\end{array}$ & 180 & $\begin{array}{l}\text { Bilateral basal } \\
\text { infiltrates }\end{array}$ \\
\hline 2 & 49 & $\mathbf{M}$ & Lymphoma & 588 & $\begin{array}{l}\text { Bilateral basal } \\
\text { infiltrates }\end{array}$ \\
\hline 3 & 44 & $\mathbf{M}$ & $\begin{array}{c}\text { Hodgkin's } \\
\text { disease }\end{array}$ & 90 & Negative \\
\hline 4 & 53 & $\mathbf{M}$ & Oesophagus & 120 & $\begin{array}{l}\text { Bilateral } \\
\text { interstitial } \\
\text { infiltrates }\end{array}$ \\
\hline
\end{tabular}


Table 2 Results of bronchoalveolar lavage in four patients with bleomycin toxicity and six control patients

\begin{tabular}{|c|c|c|c|c|c|c|}
\hline \multirow[b]{2}{*}{$\begin{array}{l}\text { Patients } \\
\text { No }\end{array}$} & \multirow[b]{2}{*}{$\begin{array}{l}\text { Total cells } \times 10^{6} \\
100 \mathrm{ml} \text { lavage }\end{array}$} & \multicolumn{5}{|l|}{$\%$ of cell } \\
\hline & & $\begin{array}{l}\text { Alveolar } \\
\text { Macrophages }\end{array}$ & Lymphocytes & $\begin{array}{l}\text { Polymorphonuclear } \\
\text { cells }\end{array}$ & Eosinophils & Basophils \\
\hline $\begin{array}{l}1 \\
2 \\
3 \\
4\end{array}$ & $\begin{array}{r}8 \\
5 \\
12 \\
6\end{array}$ & $\begin{array}{l}67 \\
89 \\
74 \\
76\end{array}$ & $\begin{array}{r}3 \\
5 \\
15 \\
11\end{array}$ & $\begin{array}{r}23 \\
6 \\
9 \\
9\end{array}$ & $\begin{array}{l}6 \\
0 \\
2 \\
4\end{array}$ & $\begin{array}{l}1 \\
0 \\
0 \\
0\end{array}$ \\
\hline $\begin{array}{l}\text { Patients } \\
\text { Mean (SEM) }\end{array}$ & $7 \cdot 7(2 \cdot 7)$ & $76 \cdot 4(4)$ & $8 \cdot 6(3)$ & $11 \cdot 8(2)$ & $3(2)$ & $0.3(0.2)$ \\
\hline $\begin{array}{l}\text { Controls } \\
\text { Mean (SEM) }\end{array}$ & $6 \cdot 5(1 \cdot 7)$ & $92.0(1.2)$ & $7 \cdot 0(0.4)$ & $1.4(0 \cdot 2)$ & $0.17(0.2)$ & $0(0)$ \\
\hline
\end{tabular}

cocytes and total inflammatory cells recovered was found at four weeks. After about eight weeks of treatment the cell recovery returned to the baseline level but the increased percentage of polymorphonuclear leucocytes persisted. Radiographic infiltrates were present at 14-16 weeks, when the only abnormality in the lavage fluid was increased polymorphonuclear leucocytes.

Our patients with bleomycin pulmonary toxicity were studied at a time of symptomatic or radiographically evident disease. The total number of lavage fluid cells recovered was similar to that in controls, but there was a significant increase in both the percentage and the total number of lavage polymorphonuclear leucocytes and eosinophils in those with toxicity. Our lavage results in bleomycin toxicity are compatible with those seen in the later stages of development of bleomycin induced interstitial fibrosis in animal models. ${ }^{2-4}$ This supports the validity of these models for the study of bleomycin pneumonitis, and also supports the clinical impression that, at the time of symptomatic and radiographic abnormalities in patients, fibrosis may have already occurred. The findings in our patients are similar to those previously described in idiopathic pulmonary fibrosis, where the lavage fluid usually shows a neutrophil predominant alveolitis. ${ }^{6}$ This is consistent with data from histological specimens since the changes seen with bleomycin toxicity are similar to those in idiopathic fibrosis. ${ }^{7}$

On the basis of studies in dogs, Fahey $e t a^{3}$ have suggested that an increase in lavage polymorphonuclear leucocytes in patients receiving bleomycin may be diagnostic of drug induced lung disease. We think that this finding is consistent with the diagnosis but not specific, since we have noted increased lavage fluid neurtrophils with other causes of diffuse lung disease in immunosuppressed patients receiving chemotherapy. ${ }^{8}$ Studies in patients before the development of overt pulmonary toxicity might be helpful in assessing the early inflammatory response as seen in animals, and in suggesting which patients are at risk of developing interstitial fibrosis.

\section{References}

I White DA, Stover DE. Severe bleomycin-induced pneumonitis: clinical features and response to corticosteroids. Chess 1984;88723-8.

2 Thrall RS, Barton RW, D'Amato DA, Sulavik SB. Differentia cellular analysis of bronchoalveolar lavage fluid obtained various stages during development of bleomycin-induced pup monary fibrosis in the rat. Am Rev Respir Dis 1982;126:488-92

3 Fahey PJ, Utell MJ, Mayewski RJ, Wandtke JD, Hyde RW Early diagnosis of bleomycin pulmonary toxicity using bron choalveolar lavage in dogs. Am Rev Respir Dis 1982;126:126-30.

4 Wesselius LJ, Catanzaro A, Wasserman SI. Neutrophil chemoe tactic activity generation by alveolar macrophages after bleo mycin injury. Am Rev Respir Dis 1984;299:485-90.

5 Thrall RS, Barton RW. A comparison of lymphocyte populations in lung tissue and in bronchoalveolar lavage fluid of rats ax various times during the development of bleomycin-induced pulmonary fibrosis. Am Rev Respir Dis 1984;129:279-83.

6 Reynolds HY, Fulmer JD, Kazmierowski JA, Roberts WC Frank MM, Crystal RG. Analysis of bronchoalveolar lavage fluid from patients with idiopathic pulmonary fibrosis and chronic hypersensitivity pneumonitis. $J$ Clin Inves 1977;59:165-75.

7 Luna MA, Bedrossian CWM, Lichtiger B, Salem PA. Interstitit pneumonitis associated with bleomycin therapy. Am J Cliz Pathol 1972;58:501-10.

8 White DA, Gellene RA, Gupta S, Cunningham-Rundles C, Sto? ver DE. Pulmonary cell populations in the immunosuppressedu patient during episodes of pneumonitis. Chest 1985;88:352-90 